\title{
ANALYSIS OF APPROACHES TO THE DEVELOPMENT AND VALIDATION OF THE METHODS OF ANALYSIS OF SOME ACTIVE PHARMACEUTICAL INGREDIENTS FROM THE GROUP OF CALCIUM CHANNEL BLOCKERS IN DRUGS AND BIOLOGICAL LIQUIDS
}

\author{
LILIYA LOGOYDA
}

Department of Pharmaceutical Chemistry, I. Horbachevsky Ternopil State Medical University, Ukraine

Email: logojda@tdmu.edu.ua

Received: 16 Feb 2019, Revised and Accepted: 06 Apr 2019

\section{ABSTRACT}

Calcium channel blockers prevent calcium from entering cells of the heart and blood vessel walls, resulting in lower blood pressure. Calcium channel blockers, also called calcium antagonists, relax and widen blood vessels by affecting the muscle cells in the arterial walls. Physico-chemical analysis methods are increasingly being introduced into fundamental pharmaceutical research and pharmaceutical analysis practice, taking into account their high sensitivity, accuracy, specificity and expressiveness.

Analytical method development is increasingly being introduced into fundamental pharmaceutical research and pharmaceutical analysis practice, taking into account their high sensitivity, accuracy, specificity and expressiveness.

Search criteria was analytical method development for medicines from group of calcium channel blockers. Literature survey has been done in range of years 1990-2018 to make the review updated and comprehensive and to show the new approacheches to the development of the methods of analysis of calcium channel blockers. The sources were world recognized journals and key words used as filter were calcium channel blockers, amlodipine, nifedipine, verapamil, validation, method development, spectrophotometry, HPLC, UHPLC. Chromatographic methods of analysis amongst others have the greatest specificity and objectivity and allow for qualitative and quantitative determination of API in combinated dosage forms and biological fluids without prior separation of the components. We can conclude that analysts are constantly working on developing new methods of analysis and their optimization in order to save time and consumables, which also ensures the efficiency of the developed method. The main disadvantage of the described methods of API analysis can be considered long term from the beginning of chromatography to API release and specific solvents used as the mobile phase in HPLC. It is necessary to develop methods and to select such chromatographic conditions that will provide high speed and high efficiency at lower pressure of the system. This reduces the amount of used mobile phase, which reduces cost analysis accordingly, while at the same time providing the necessary specificity, accuracy and reproducibility of the results of the analysis during quality control. Also, the reduction of analysis time is achieved by simplifying the conditions for sample preparation.

Keywords: Calcium channel blockers, Amlodipine, Nifedipine, Verapamil, Validation

(C) 2019 The Authors. Published by Innovare Academic Sciences Pvt Ltd. This is an open access article under the CC BY license (http://creativecommons.org/licenses/by/4.0/) DOI: http://dx.doi.org/10.22159/ijap.2019v11i3.32498

\section{INTRODUCTION}

Calcium channel blockers prevent calcium from entering cells of the heart and blood vessel walls, resulting in lower blood pressure. Calcium channel blockers, also called calcium antagonists, relax and widen blood vessels by affecting the muscle cells in the arterial walls.

Some calcium channel blockers have the added benefit of slowing heart rate, which can further reduce blood pressure, relieve chest pain (angina) and control an irregular heartbeat.

Some calcium channel blockers are available in short-acting and long-acting forms. Short-acting medications work quickly, but their effects last only a few hours. Long-acting medications are slowly released to provide a longer lasting effect [1].

Calcium channel blockers were first identified in the lab of German pharmacologist Albrecht Fleckenstein beginning in 1964. In 1021, Avicenna introduced the medicinal use of Taxus baccata for phytotherapy in The Canon of Medicine. He named this herbal drug "Zarnab" and used it as a cardiac remedy. This was the first known use of a calcium channel blocker drug, which were not in wide use in the Western world until the 1960s. [2].

Physico-chemical analysis methods are increasingly being introduced into fundamental pharmaceutical research and pharmaceutical analysis practice, taking into account their high sensitivity, accuracy, specificity and expressiveness.

Search criteria was analytical method development for medicines from group of calcium channel blockers. Literature survey has been done in range of years 1990-2018 to make the review updated and comprehensive and to show the new approacheches to the development of the methods of analysis calcium channel blockers. The sources were world recognized journals and key words used as filter were calcium channel blockers, amlodipine, nifedipine, verapamil, validation, method development, spectrophotometry, HPLC, UHPLC.

Methods of analysis of amlidipine<smiles>CCOC(=O)C1=C(COCCN)NC(C)=C(C(=O)OC)C1c1ccccc1Cl</smiles>

Fig. 1: The chemical structures of amlodipine

Amlodipine is a synthetic dihydropyridine and a calcium channel blocker with antihypertensive and antianginal properties. Amlodipine inhibits the influx of extracellular calcium ions into myocardial and peripheral vascular smooth muscle cells, thereby preventing vascular and myocardial contraction. Chemical name of amlidipine is $3-\sim\{0\}$-ethyl 5$\sim\{0\}$-methyl 2-(2-aminoethoxymethyl)-4-(2-chlorophenyl)-6-methyl1,4-dihydropyridine-3,5-dicarboxylate (fig. 1) [3].

The State Pharmacopoeia of Ukraine (SPhU) does not have a monograph on the substance of amlodipine besylate or on the 
prepared medical form. However, the United States Pharmacopoeia regulates the determination of amlodipine besylate in substances and tablets. For identification, UV-spectrophotometry and HPLC/UV are proposed. For quantitative determination of amlodipine besylate in tablets-HPLC/UV, respectively. Chromatographic conditions for the determination of amlodipine besylate, tablets are given in the monograph of the United States Pharmacopoeia, which is used the chromatographic column of category L1 (fixed phase C18) and mobile phase consisting of three components: buffer solution of $\mathrm{pH}$ 3.0 with triethylamine, acetonitrile and methanol. The solventmobile phase, mobile phase rate- $1 \mathrm{ml} / \mathrm{min}$, detection wavelength$237 \mathrm{~nm}$. The proposed method of the United States Pharmacopeia requires a long sampling

The European Pharmacopeia has a monograph on the substance of amlodipine besylate. Identification of amlodipine besylate of the European Pharmacopeia regulates the absorption spectrophotometry in the infrared region and quantitative determinationHPLC/UV. As a solvent, methanol is used, mobile phase- $2.3 \mathrm{~g} / \mathrm{l}$ of ammonium acetate solution $\mathrm{P}$ : methanol $\mathrm{P}(30: 70, \mathrm{~V} / \mathrm{V})$, mobile phase rate- $1.5 \mathrm{ml} / \mathrm{min}$, detection wavelength-237 $\mathrm{nm}$.

Methods of quantitative determination of amlodipine besylate by the method of spectrophotometry are described in the scientific literature-by products of reaction with various reagents and by their own light absorption, kinetic-spectrophotometric method in substance and drugs, by the method of inhibition of chemiluminescence, by chromatography methods.

Historical development of methods for the quantitative determination of amlodipine besylate in substances and drugs is closely related to the development of analytical methods themselves and pharmaceutical analysis in general. Nowadays the literature contains a large number of scientific papers devoted to the quantitative determination of amlodipine besylate and other APIs in one medical form, since amlodipine is used in combination with different APIs for the treatment of hypertension. Specifically, the researchers proposed spectrophotometric methods for the determination of amlodipine besylate and atorvastatin in tablets [46], Dake A. S. et al-spectrophotometric method for the determination of amlodipine besylate and enalapril maleate in tablets [7], Jain H. K. et al.-spectrophotometric method for the determination of amlodipine besylate and lisinopril in tablets [8-10], Meyya S. N. et al.-spectrophotometric method for the determination of amlodipine besylate and benazepil in medical form [11-15], Wankhede S. B. et al.-spectrophotometric method for the determination of amlodipine besylate, losartan potassium and hydrochlorothiazide in tablets [16].

The HPLC method is widely used in the analysis of amlodipine besylate both in substance and in mono-and combined drugs. Simple, precise, sensitive methods are developed today-liquid chromatography, combination of TLC with densitometric determination, HPLC/UV, HPLC/DMD, HPLC/MS. For example, scientists of the National Pharmaceutical University conducted the verification of the method of reverse-phase HPLC with UVspectrophotometric detection, which is described in the $\mathrm{EPh}$. Validation characteristics such as correctness, linearity, precision, specificity, and intra-laboratory precision were studied. This HPLC/UV method can be reproduced in the laboratory and does not depend on the excipients [17-22].

Sivakumar et al. proposed the method of reverse-phase HPLC with UVspectrophotometric detection of amlodipine besylate. The method was proposed using a mobile phase containing the mixture of methanol, acetonitrile and $15 \mathrm{mmol} \mathrm{K}_{2} \mathrm{NR}_{4}$ buffer solution ( $\mathrm{pH}$ 5.33) (10:42.08:47.92, V/V/V), mobile phase rate-1.12 $\mathrm{ml} / \mathrm{min}[23,24]$.

Argekar A. P. et al. proposed the combination of liquid chromatography and TLC with densitometric determination of amlodipine and atenolol in tablets using a mixture of methylene chloride, methanol, ammonia solution (8.8:1.3:0.1, V/V) as mobile phase [25-27].

Reverse-phase HPLC with UV-spectrophotometric detection method for the determination of amlodipine besylate and enalapril maleate in medical form was described by Bharat G. Chaudhari. The developed method uses the chromatographic column Phenomenex C18, $5 \mu \mathrm{m}, 250 \mathrm{~mm} \times 4.6 \mathrm{~mm}$ i.d. column and mobile phase-a mixture of methanol, acetonitrile, water $(40: 50: 10, \mathrm{~V} / \mathrm{V} / \mathrm{V})$. The method is linear in the range of concentrations of $0.5-6.0 \mu \mathrm{g} / \mathrm{ml}$ and $0.5-8.0$ $\mu \mathrm{g} / \mathrm{ml}$ of enalapril maleate and amlodipine besylate, respectively. The retention time for enalapril maleate and amlodipine besylate was 2.27 and $5.07 \mathrm{~min}$, respectively [28, 29].

Sohan S Chitlange et al. developed the method of reverse-phase HPLC with UV-spectrophotometric detection of amlodipine and metoprolol in tablets using Kromasil C18 column (250 x 4.6 mm, 5 $\mu \mathrm{m})$ and mobile phase-a mixture of $0.02 \mathrm{M}$ phosphorus buffer solution and acetonitrile (70:30 V/V, pH 3.0), mobile phase rate-1.0 $\mathrm{ml} / \mathrm{min}$, detection wavelength-221 nm [31].

The retention time for amlodipine was $2.57 \mathrm{~min}$ and metoprolol was $4.49 \mathrm{~min}$. The linearity of the method was determined in the range of concentrations of $10-110 \mu \mathrm{g} / \mathrm{ml}$ of both analytes [32-34]. The same authors proposed the method of reverse-phase HPLC with UVspectrophotometric detection of the determination of amlodipine and valsartan in capsules using the Kromasil C18 column (250 x 4.6 $\mathrm{mm}, 5 \mu \mathrm{m}$ ) and mobile phase-a mixture of acetonitrile and phosphate buffer solution $(0.02 \mathrm{M}, \mathrm{pH} 3.0),(56: 44 \mathrm{~V} / \mathrm{V})$, mobile phase rate-1.0 $\mathrm{ml} / \mathrm{min}$, detection wavelength-234 $\mathrm{nm}$. The retention time for amlodipine was $3.07 \mathrm{~min}$ and valsartan was 6.20 min. Shi-Ying Dai et al. developed the method of reverse-phase HPLC with UV-spectrophotometric detection of the determination of amlodipine and ramipril in the presence of impurities in the mode of gradient elution [35]. Prathyusha W. et al. proposed the HPLC/UV method for the determination of amlodipine besylate, alixerine hemifumarate and hydrochlorothiazide in drugs using losartan as internal standard. Chromatographic conditions: Inestsil columnODS C18 $(100 \times 4.6 \mathrm{~mm}, 5 \mu \mathrm{m})$, mobile phase-a mixture of $0.1 \mathrm{M}$ ammonia buffer solution and acetonitrile $(65: 35 \mathrm{~V} / \mathrm{V})$, mobile phase rate $-1.0 \mathrm{ml} / \mathrm{min}$, detection wavelength- $232 \mathrm{~nm}$. The retention time for amlodipine was $5.22 \mathrm{~min}$, alixerine hemifumarate was $3.90 \mathrm{~min}$, and hydrochlorothiazide was $1.91 \mathrm{~min}$ [36-49].

Shalini Pant et al. described the HPLC/UV method for the determination of amlodipine besylate and bisoprolol fumarate in drugs using a C18 column ( $250 \times 4.6 \mathrm{~mm}, 5 \mu \mathrm{m})$ and mobile phase-a mixture of acetonitrile and phosphate buffer solution $(50: 50 \mathrm{~V} / \mathrm{V})$, mobile phase rate $-1.0 \mathrm{ml} / \mathrm{min}$, detection wavelength-230 $\mathrm{nm}$. The retention time for amlodipine was $6.4 \mathrm{~min}$, bisoprolol was $4.4 \mathrm{~min}$. Linearity of the method was studied in the range of concentrations of $1.3-10.8 \mu \mathrm{g} / \mathrm{ml}[50]$.

Reverse-phase HPLC with UV-spectrophotometric detection method for the determination of amlodipine besylate and telmisartan in the medical form was described by Kayal SD et al. The proposed method uses the chromatography column Prontosil C18, $5 \mu \mathrm{m}, 250 \mathrm{~mm} \times 4.6 \mathrm{~mm}$ i.d. column and mobile phase-a mixture of methanol, potassium dihydrogen phosphate buffer solution pH $4.5(75: 25 \mathrm{~V} / \mathrm{V})$, mobile phase rate-1.4 $\mathrm{ml} / \mathrm{min}$, detection wavelength $-240 \mathrm{~nm}$. The method is linear in the range of concentrations of $2-20 \mu \mathrm{g} / \mathrm{ml}$ and $16-160 \mu \mathrm{g} / \mathrm{ml}$ amlodipine and telmisartan, respectively. The retention time for amlodipine and telmisartan was 3.12 and $5.80 \mathrm{~min}$, respectively [51-55].

Raju et al. described the method of reversed-phase HPLC with UVspectrophotometric detection for the determination of amlodipine and perindopril in combined medical form using Xterra C18 column $(100 \times 4.6 \mathrm{~mm}, 5 \mu \mathrm{m})$ and mobile phase-a mixture of phosphorus buffer soultion and acetonitrile $(65: 35 \mathrm{~V} / \mathrm{V})$, mobile phase rate- 0.6 $\mathrm{ml} / \mathrm{min}$, detection wavelength-237 $\mathrm{nm}$. Linearity was studied in the range of concentrations of 10-50 $\mu \mathrm{g} / \mathrm{ml}$ of amlodipine and 200-1000 $\mu \mathrm{g} / \mathrm{ml}$ of perindopril. The retention time for amlodipine and perindopril was 8.51 and $5.28 \mathrm{~min}$, respectively [56-64].

The literature describes bioanalytical methods for the quantitative determination of amlodipine besylate in plasma. Bhatt J. et al. developed the express method for the determination of amlodipine in blood plasma using HPLC/MS and HPLC/MS/MS. The proposed method uses the chromatographic column Hypersil BDS C18, and internal standard-imipramide. The method is linear in the range of concentrations of $0.1-10 \mathrm{ng} / \mathrm{ml}$. The total time of chromatography was $3.2 \mathrm{~min}$ [65]. 
Alsarra I. A. proposed the bioanalytical method for the determination of amlodipine in blood plasma and medical form using the developed methodology for the study of pharmacokinetics. The method was proposed using C18 Hypersil HyPurity column (3 microm, $3.9 \mathrm{~mm}$ id $\mathrm{x}$ $150 \mathrm{~mm}$ ) and mobile phase containing a mixture of acetonitrile, potassium dihydrogen phosphate buffer solution $(0.05 \mathrm{M})$ and acetic acid (62:38:0.1 V/V/V), mobile phase rate-1.8 $\mathrm{ml} / \mathrm{min}$. LOD of amlodipine besylate-1.0 ng/ml, limit of quantitation (LOQ) -10.0 $\mathrm{ng} / \mathrm{ml}$. The developed method was used for the analysis of amlodipine tablets and for the study of pharmacokinetics [66].

Feng Y. et al. described the HPLC/MS method for the determination of amlodipine in blood plasma. After extraction with ethyl acetate using the internal standard of nicardin, the chromatographic column C18 and mobile phase-a mixture of methanol and 1\% acetic acid solution (65:35 V/V) were used [67].

Zarghi A. et al. developed the bioanalytical method for the determination of amlodipine in blood plasma using the described methodology for the study of pharmacokinetics. The developed procedure uses the chromatographic column Nucleosil C8, $5 \mu \mathrm{m}, 125$ $\mathrm{mm} \times 4.6 \mathrm{~mm}$ i.d. column and mobile phase-a mixture of acetonitrile and $0.01 \mathrm{M}$ sodium dihydrogenphosphate buffer solution (37:63, $\mathrm{V} / \mathrm{V}$ ), mobile phase rate $-1.5 \mathrm{ml} / \mathrm{min}$, detection wavelength-239 $\mathrm{nm}$. Linearity of the method was studied in the concentration range of $0.5-16 \mathrm{ng} / \mathrm{ml}$. LOQ of amlodipine besylate- $0.2 \mathrm{ng} / \mathrm{ml}$ [68].

Bahrami G. et al. proposed the express HPLC method for the determination of amlodipine in serum with fluorescence detection and application of the developed method for pharmacokinetic studies. Amlodipine was extracted from the blood serum of ethyl acetate. Pre-colon derivatization with 4-chloro-7-nitrobenzofuran was carried out. Chromatography was performed using the C18 column and mobile phase consisting of phosphate buffer solution $\mathrm{pH}$ $2.5(1 \mathrm{ml} / \mathrm{l}$ of triethylamine and methanol), mobile phase rate- 2.8 $\mathrm{ml} / \mathrm{min}$. As internal standard, propranolol was used. The method of quantitative determination of amlodipine besylate in blood serum was linear in the range of concentrations of $0.25-16 \mathrm{ng} / \mathrm{ml}$. LOQ was $0.25 \mathrm{ng} / \mathrm{ml}$. The developed method found its application for the study of bioequivalence of tablets of amlodipine $10 \mathrm{mg}[69,70]$.

Scientists Y. Ma, F. Qin, X. Sun studied the pharmacokinetics of amlodipine using UHPLC/MS. Chromatography was performed using the chromatographic column ACQUITY UPLC BEH C (18) column (50 $\mathrm{mm} \times 2.1 \mathrm{~mm}$, id, 1.7 microm) and gradient elution (mobile phasewater and acetonitrile) with mobile phase rate- $0.35 \mathrm{ml} / \mathrm{min}$, internal standard-nimodipine The method was linear in the range of $0.15-16.0 \mathrm{ng} / \mathrm{ml}$ with lower limit of quantitation (LLOQ)-0.15 $\mathrm{ng} / \mathrm{ml}$. The described method was used to study pharmacokinetics in clinical studies [71, 72].

Scientists Q. Yu, Z. Y. Hu, F. Y. Zhu developed HPLC/MS method for determination of amlodipine and atorvastatin in blood plasma. The method was proposed using a C18 chromatographic column and gradient elution of mobile phase containing a $0.1 \%$ solution of musk acid in water and $0.1 \%$ of solution of musk acid in acetonitrile, mobile phase rate- $0.4 \mathrm{ml} / \mathrm{min}$. The developed method was used for the determination of amlodipine and atorvastatin in joint application for the treatment of patients with hypertension [73].

Wei X. et al. proposed the bioanalytical method for the determination of amlodipine and nicardin in blood plasma using a monolithic cation exchange column. The developed method was linear in the range of concentrations of $0.5-50.0 \mathrm{ng} / \mathrm{ml}$ of both analytes, correlation coefficient-0.998, LOQ-0.2 ng/ml of amlodipine and nicardin [74].

Scientists Ramani A. V., Sengupta P., Mullangi R. developed the UHPLC/MS method for the determination of amlodipine, simvastatin and valsartan in blood plasma with the use of pharmacokinetics. The method was proposed using the chromatographic column X-Terra C18 column and mobile phase containing a mixture of $0.02 \mathrm{M}$ ammonium $(\mathrm{pH} 4.5)$ and acetonitrile $(20: 80 \mathrm{~V} / \mathrm{V})$, mobile phase rate $-0.5 \mathrm{ml} / \mathrm{min}$. The method is linear in the range of $0.5-50 \mathrm{ng} / \mathrm{ml}$ of valsartan and $0.2-50 \mathrm{ng} / \mathrm{ml}$ of amlodipine and simvastatin. The correlation coefficient was more than 0.996 for all analytes. The developed method was used for pharmacokinetic studies [75-97].

\section{Methods of analysis of nifedipine}<smiles>COC(=O)C1=C(C)NC(C)=C(C(=O)OC)C1c1ccccc1[N+](=O)[O-]</smiles>

Fig. 2: The chemical structures of nifedipine

Nifedipine is a dihydropyridine calcium channel blocking agent. Nifedipine inhibits the transmembrane influx of extracellular calcium ions into myocardial and vascular smooth muscle cells, causing dilatation of the main coronary and systemic arteries and decreasing myocardial contractility. Chemical name of nifedipine is dimethyl 2,6-dimethyl-4-(2-nitrophenyl)-1,4dihydropyridine-3,5-dicarboxylate (fig. 2) [3].

The State Pharmacopoeia of Ukraine (SPhU) has a monograph on the substance of nifedipine. For identification of the substance of nifedipine, the SPhU offers the determination of melting point, absorption spectrophotometry in the infrared region, TLC (mobile phase-ethyl acetate P-cyclohexane (40:60)) and qualitative reaction of formation of azo dye after the previous restoration of nitro group to amino group, quantitative determination-cerimetry. The United States Pharmacopoeia regulates the definition of nifedipine in substances and tablets. For identification, the definition of absorption spectrophotometry in the infrared region and UV-spectrophotometry is proposed. For quantitative determination of nifedipine in tabletsHPLC/UV method. In accordance with this article, the following chromatographic conditions are used: chromatographic column of category L1 (with fixed phase C18) with sixe $4.6 \mathrm{~mm}$ x $250 \mathrm{~mm}$; mobile phase-acetonitrile: methanol: water (25:25:50); solventmethanol, wavelength- $235 \mathrm{~nm}$, flow rate- $1.0 \mathrm{ml} / \mathrm{min}$.

The European Pharmacopoeia has a monograph on the substance of nifedipine. For identification, it is proposed to determine the melting point, absorption spectrophotometry in the infrared region, TLC (mobile phase-a mixture of ethyl acetate $\mathrm{P}$ and cyclohexane P (40:60 $\mathrm{V} / \mathrm{V}$ ) and qualitative reaction to the primary aromatic amino groupreaction of formation of azo dye (after preliminary reduction of nitro group to amino group). For the quantitative determination of nifedipine-method of cerimetry.

Methods of quantitative determination of nifedipine by methods of spectrophotometry and chromatography are described in the scientific literature.

Scientists Sathis Kumar Dinakaran, Babitha Alluri, Koushik Reddy Annareddy developed the spectrophotometric method for the determination of nifedipine and atorvastatin in substances and medical form. For the analysis of nifedipine and atorvastatin, it is recommended to use the UV-spectrophotometry method in methanol, whose solution has maxima at wavelengths of $237 \mathrm{~nm}$ (atorvastatin) and $297 \mathrm{~nm}$ (nifedipine) [98].

Revathi R. et al. proposed spectroscopic determination of nifedipine using $40 \%$ sodium salicylate solution as hydrotropic solubilizing agent. The solutions of complex have absorption maxima at $350 \mathrm{~nm}$ and are subject to the Bouguer-Lambert-Beer's law in the range of concentrations of $20-100 \mu \mathrm{g} / \mathrm{ml}$. The proposed method was successfully applied to determine APIs in tablets $[99,100]$.

Spectrophotometric determination of nifedipine in drugs, blood serum and urine using oxidation-reduction reactions was developed by scientists Tulasamma P. and Venkateswarlu P. The proposed methods are based on the restoration of the nitro group to the amino group. Method A is based on oxidation followed by the combination of nifedipine and 3-methyl-2-benzothiazolinone hydrazone in the 
presence of iron chloride to form a green chromogen color at 685 $\mathrm{nm}$. Method B is based on the oxidation reaction of nifedipine brucine to form a purple chromogen at $546 \mathrm{~nm}$ [101].

Modi Dixita V., Patel Paresh U. developed the method for determination of nifedipine and telmisartan in mixtures. As a solvent, methanol was used. The maximum absorption of nifedipine$235 \mathrm{~nm}$ and telmisartan-297 $\mathrm{nm}$. The method was linear in the range of $2-20 \mu \mathrm{g} / \mathrm{ml}$ of nifedipine and $1-18 \mu \mathrm{g} / \mathrm{ml}$ of telmisartan. The developed method can be used in routine analysis of drugs [102].

Scientists AlGhannam S. M., AlOlyan A. M. proposed the spectrofluorimetric method for the determination of certain substances from the group of 1,4-dihydropyridine, namely nicardipine, nifedipine, isradipine in drugs and biological fluids. The method is based on the restoration of nicardipine, nifedipine, isradipine from $\mathrm{Zn} / \mathrm{HCl}$, and fluorescence measurement $\left(\lambda_{\mathrm{em}} / \lambda_{\mathrm{ex}}\right)$ at $460 / 364,450 / 393$ and $446 / 360$ $\mathrm{nm}$, respectively. The method was linear in the range of concentrations of $0.4-6.0,0.2-4.0$ and $0.1-9.0 \mu \mathrm{g} / \mathrm{ml}$ with LOD $0.0028,0.017$ and 0.016 $\mu \mathrm{g} / \mathrm{ml}$, respectively. The proposed method was successfully applied for the determination of nicardipine, nifedipine, isradipine in medical form and biologically advanced liquids (plasma, urine) [103].

Scientists Bing L., Hu D. F., Liu F. developed the HPLC/UV method for the determination of nifedipine and atenolol in tablets. According to the proposed method, the following chromatographic conditions are used: chromatographic column Phenomenex-ODS 3 column (250 $\mathrm{mm} \times 4.60 \mathrm{~mm}, 5 \mu \mathrm{m})$; mobile phase -methanol: water: phosphate buffer solution; wavelength-240 $\mathrm{nm}$, flow rate $-1.0 \mathrm{ml} / \mathrm{min}$. The linear dependence is maintained at intervals of $10-250 \mu \mathrm{g} / \mathrm{ml}$ of atenolol (correlation coefficient 0.9999) and $4-100 \mu \mathrm{g} / \mathrm{ml}$ of nifedipine (correlation coefficient 1.0000) [104].

Scientists Cristobal Galan-Rodriguez, Jaime González-Álvarez, Màrius Valls-Remolí proposed the UHPLC/UV for the determination of nifedipine and its impurities. The chromatography column Acquity Shield $\mathrm{RP}_{18}(50 \times 3.0 \mathrm{~mm}, 1.7 \mathrm{~m})$ and mobile phase -a mixture of $10 \mathrm{mmol}$ ammonium ( $\mathrm{pH} \mathrm{4.5)}$ and methanol, were used at flow rate of $0.5 \mathrm{ml} / \mathrm{min}$. The total time of chromatography was 11 min. The method was linear in the range of $0.25-1.5 \mu \mathrm{g} / \mathrm{ml}$ of nifedipine and its impurities. LOQ-0.05 $\mu \mathrm{g} / \mathrm{ml}[105,106]$.

Rosseel M. T. et al. developed the method for determination of nifedipine in blood plasma using capillary gas chromatography with nitrogen detection. Nifedipine was extracted from plasma with toluene. Nitrendipine was used as an internal standard. The method was linear in the range of $2-300 \mathrm{ng} / \mathrm{ml}$ [107].

Scientists Soons P. A., Schellens J. H., Roosemalen M. C., Breimer D. D. described the analysis of nifedipine and its pyridine metabolite of dihydronifedipine in blood plasma using the method of reversephase HPLC/UV. The published method in 1991 was observational and of recommendatory nature [108].

Guo Y. et al. proposed the bioanalytical method for the determination of nifedipine in plasma and its application for the study of bioequivalence. HPLC/MS method for the determination of nifedipine in blood plasma was developed. Nifedipine was extracted with diethyl ether, dimethoxane was used as an internal standard. The chromatography column BDS C (18) and mobile phase-a mixture of methanol and water $(66: 34, \mathrm{~V} / \mathrm{V})$ were used. Researches on the study of bioequivalence were conducted using the developed method of 20 volunteers [109].

Wang D., Jiang K., Yang Sh. developed the bioanalytical method for the determination of nifedipine in blood plasma by the method of UHPLC/MS using the developed methodology for the study of pharmacokinetics. The chromatographic determination was performed using the chromatography column UPLC ${ }^{\mathrm{TM}} \mathrm{BEH} \mathrm{C}$ (18) column and mobile phase-mixture of acetonitrile and $10 \mathrm{mmol} / \mathrm{l}$ of ammonium acetate solution $(75: 25, \mathrm{~V} / \mathrm{V})$ at flow rate of $0.2 \mathrm{ml} / \mathrm{min}$. The method was linear in the range of concentrations of $0.104-52.0 \mathrm{ng} / \mathrm{ml}, \mathrm{LOQ}-0.104$ $\mathrm{ng} / \mathrm{ml}$. The method was fully validated and successfully applied to study the pharmacokinetics of nifedipine tablets [110].

Le Guellec C. et al. described the definition of nifedipine in blood plasma by the method of gas chromatography. The developed method was linear in the concentration range of $0.5-500 \mathrm{ng} / \mathrm{ml}$, LOQ- $0.5 \mathrm{ng} / \mathrm{ml}$. The method was used to monitor the concentration of nifedipine in patients receiving this drug [111].

Zendelovska D. et al. proposed the bioanalytical method for determination of nifedipine in blood plasma. Chromatography was carried out using the mobile phase-a mixture of $0.02 \mathrm{~mol} / \mathrm{l}$ potassium dihydrogen phosphate $(\mathrm{pH} 4.8)$ and acetonitrile $(42: 58, \mathrm{~V} / \mathrm{V})$ at wavelength $240 \mathrm{~nm}$. Linearity of method was determined in the range of concentrations $5.0-200.0 \mathrm{ng} / \mathrm{ml}, \mathrm{LOQ}-5.0 \mathrm{ng} / \mathrm{ml}[112,113]$.

Scientists Gurley B. J., Buice R. G., Sidhu P. developed the reverse-phase HPLC/UV method for determination of nifedipine in plasma using an internal standard of 17- $\alpha$-ethinylestradiol, mobile phase-a mixture of phosphate buffered solution (pH 6.1), methanol, acetonitrile (20:35:45 $\mathrm{V} / \mathrm{V} / \mathrm{V}$ ), chromatography column muBondapak C-18 column at wavelength of $235 \mathrm{~nm}$ and flow rate of $1.0 \mathrm{ml} / \mathrm{min}[114,115]$.

Abou-Auda H. S. et al. described the bioanalytical method for the determination of nifedipine in plasma and application of the developed method for the study of pharmacokinetics. Chromatography was performed using a C18 column, mobile phasea mixture of acetonitrile, methanol and water $(35: 17: 48, \mathrm{~V} / \mathrm{V} / \mathrm{V})$ and internal standard-diazepam. The method was linear in the concentration range of $10-200 \mathrm{ng} / \mathrm{ml}$ and was successfully applied for pharmacokinetic studies [116].

Scientists Mosab A., Zahaa A., Momir M. proposed the HPLC/UV method for determination of nifedipine in plasma of rats to study pharmacokinetics and bioequivalence. In this method, the chromatographic column Phenomenex Luna-C18 (250 x $4.6 \mathrm{~mm}, 5$ $\mu \mathrm{m})$ and mobile phase-a mixture of ammonium, methanol, acetonitrile (55: 43: $2, \mathrm{~V} / \mathrm{V} / \mathrm{V}$ ), flow rate- $0.8 \mathrm{ml} / \mathrm{min}$, wavelength$235 \mathrm{~nm}$. Linearity of method was determined in the range of concentrations $5.00-200 \mathrm{ng} / \mathrm{ml}, \mathrm{LOQ}-6 \mathrm{ng} / \mathrm{ml}$ [117].

Scientists Yritia M., Parra P., Iglesias E., Barbanoj J. M. developed the HPLC/UV method for determination of nifedipine in blood plasma using the chromatographic column C18 and mobile phase-a mixture of acetonitrile and $13 \mathrm{mmol}$ phosphate buffer solution $\mathrm{pH} 7$ (65:35, $\mathrm{V} / \mathrm{V}$ ) at wavelength of $338 \mathrm{~nm}$. LOD-2 $\mathrm{ng} / \mathrm{ml}$. The developed method was successfully applied for bioequivalence [118].

Wang X. D. et al. described the HPLC/MS method for the determination of nifedipine and dihydronifedipine in blood plasma, followed by its use for the study of clinical interaction of drugs. Nitrendipine was used as an internal standard. Chromatographic column-Hypersil BDS C (18) column (50 mm x $2.1 \mathrm{~mm}$, i.d., 3 microm). Total chromatography time was $2.5 \mathrm{~min}$. The method was linear in the range of concentrations of $0.5-100 \mathrm{ng} / \mathrm{ml}$ of both analytes. LOQ of nifedipine and dihydronifedipine- $0.5 \mathrm{ng} / \mathrm{ml}$. The developed method was successfully applied for pharmacokinetic studies [119].

Other scientists also developed the method for determination of nifedipine and dihydronifedipine in blood plasma using the chromatographic column $\mathrm{C} 18$ and mobile phase-a mixture of methanol and $50 \mathrm{mmol}$ ammonium acetate solution $(50: 50, \mathrm{~V} / \mathrm{V})$. The method was linear in the range of concentrations of $0.5-100$ $\mathrm{ng} / \mathrm{ml}$ of both analytes [120-121].

Methods of analysis of verapamil<smiles>COc1ccc(CCN(C)CCCC(C#N)(c2ccc(OC)c(OC)c2)C(C)C)cc1OC</smiles>

Fig. 3: The chemical structures of verapamil

Verapamil is a phenylalkylamine calcium channel blocking agent. Verapamil inhibits the transmembrane influx of extracellular calcium ions into myocardial and vascular smooth muscle cells, causing dilatation of the main coronary and systemic arteries and 
decreasing myocardial contractility. Chemical name of verapamil is 2(3,4-dimethoxyphenyl)-5-[2-(3,4-dimethoxyphenyl)ethyl-methylamino]-2-propan-2-ylpentanenitrile (fig. 3) [3].

The State Pharmacopoeia of Ukraine (SPhU) has a monograph on the substance of verapamil hydrochloride and on verapamil hydrochloride tablets. To identify the substance of verapamil hydrochloride, SPhU offers UV-spectrophotometry, absorption spectrophotometry in the infrared region, TLC (mobile phase-diethylamine P-cyclohexane (15:85)), quantitative determination-alkalimetry, potentiometric titration. For identification of verapamil hydrochloride in tablets, $\mathrm{SPhU}$ proposes UV-spectrophotometry, HPLC/UV (mobile phase-a mixture of heptylamine $\mathrm{P}^{\mathrm{N}}$-acetic acid of ice $\mathrm{P}$-acetonetrile P-solution of 1.36 $\mathrm{g} / \mathrm{l}$ of sodium acetate $\mathrm{P}(1: 4.7: 58: 1.37))$, qualitative reaction to chlorides. For quantitative determination of verapamil hydrochloride in tablets-UV-spectrophotometry.

The United States Pharmacopoeia regulates the definition of verapamil hydrochloride in substance, tablets and injection solution. In order to identify verapamil hydrochloride in the substance, determination is made by absorption spectrophotometry in the infrared region, HPLC/UV (mobile phase-analogous to SPhU), qualitative reaction to chlorides, for quantitative determinationacidimetry in non-aqueous medium. For the identification of verapamil hydrochloride in tablets, the United States Pharmacopoeia offers the absorption spectrophotometer method in the infrared area and HPLC/UV. The drug Verapamil hydrochloride, tablets are described in the monograph of the United States Pharmacopoeia. According to this article, the HPLC/UV is regulated by the following chromatographic conditions: chromatographic column of category L1 (fixed phase C18) size $4.6 \mathrm{~mm} \times 125$ or $150 \mathrm{~mm}$; mobile phaseacetonitrile: 2-aminoheptane: solution A $(0.015 \mathrm{M}$ solution of sodium acetate containing $33 \mathrm{ml} / \mathrm{l}$ of acetic acid) in ratio (30:0.5:70); wavelength- $278 \mathrm{~nm}$, flow rate $-0.9 \mathrm{ml} / \mathrm{min}$.

The European Pharmacopoeia [3] suggests identifying verapamil hydrochloride UV-spectrophotometry substance, absorption spectrophotometry in the infrared region, TLC (mobile phasediethylamine P-cyclohexane (15:85)) and qualitative reaction to chlorides, quantitative determination-alkalimetry potentiometric titration.

Methods of quantitative determination of verapamil hydrochloride by spectrophotometry, electrochemical method and chromategraphy methods are described in the scientific literature.

Salh D. M. proposed spectrophotometric determination of verapamil in drugs using bromotymol blue. The method is based on the reaction of complex formation. The reaction product was extracted with tetrachloromethane and the optical density was measured at $420 \mathrm{~nm}$. The developed method was completely validated. Coefficient of cocorrelation-0.9951, LOQ-0.009253 $\mu \mathrm{g} / \mathrm{ml}$. The method was successfully applied for the analysis of medical form containing verapamil hydrochloride (tablets, capsules, ampoules) [122].

Scientists Rahman N., Hoda M. N. developed the spectrophotometric method for the determination of verapamil hydrochloride in drugs using chloramine-T. The method is based on the oxidation reaction of verapamil with chloramine-T in acidic environment. The solutions of the complex are yellow in color and have absorption maxima at $425 \mathrm{~nm}$ and are subject to the Bouguer-Lambert-Beer's law in the range of concentrations of $0-340 \mu \mathrm{g} / \mathrm{ml}$. The proposed method was successfully applied to determine verapamil hydrochloride in medical form [123].

Scientists Nafisur Rahman and Syed Najmul Hejaz Azmi proposed the spectrophotometric method of verapamil hydrochloride in drugs using $\mathrm{N}$-bromosicinamide. The method is based on the oxidation of verapamil hydrochloride by $N$-bromosicinamide in chlorinated acid environment at room temperature to give a yellow colored product having maximum absorption at $415 \mathrm{~nm}$ and subject to the BouguerLambert-Beer's law for the concentration range 10.0-200.0 $\mu \mathrm{g} / \mathrm{ml}$. The developed method was successfully applied for the determination of verapamil hydrochloride in the drug [124].

Nafisur Rahman et al. described two spectrophotometric methods for the determination of verapamil hydrochloride in drugs. Method
A is based on the oxidation of verapamil potassium hydrochloride with metaperiodate in environment of sulphate acid to the formation of colored reaction product having a maximum absorption at $425 \mathrm{~nm}$ and subject to the Bouguer-Lambert-Beer's Law in the range of $12.5-187.5 \mu \mathrm{g} / \mathrm{ml}$. Method $B$ is based on the formation of colored reaction product with tropaeolin 00 at $\mathrm{pH} 4.0$, which is excreted by chloroform, has a maximum absorption at $400 \mathrm{~nm}$ and is subject to the Bouguer-Lambert-Beer's law in the range of 2.0-30.0 $\mu \mathrm{g} / \mathrm{ml}$. Both methods have found their application in the analysis of drugs containing verapamil hydrochloride [125-130].

Ivanova V. et al. developed the HPLC/UV method for determination of verapamil in blood plasma using the chromatographic column Lichrospher 60 RP-select B column (250 mm $\times 4 \mathrm{~mm}$ ID, 5 $\mu \mathrm{m})$ and mobile phase-a mixture of $40 \%$ acetonitrile and $0.025 \mathrm{~mol} / \mathrm{l}$ of potassium dihydrogenphosphate $\mathrm{pH} 2.5$, flow rate-1 $\mathrm{ml} / \mathrm{min}$, detection wavelength-200 nm. The method was linear in the range of $10-500 \mathrm{ng} / \mathrm{ml}$. The developed method was successfully applied for routine analysis of verapamil in blood plasma [131-133].

Sawicki W. proposed the validated method for determination of verapamil and its metabolite norverpamil in blood plasma. LOD of verapamil is $0.924 \mathrm{ng} / \mathrm{ml}$, LOQ $-3.080 \mathrm{ng} / \mathrm{ml}$. LOD of norvermapamil-0.030 $\mathrm{ng} / \mathrm{ml}$, LOQ $-1.001 \mathrm{ng} / \mathrm{ml}$. The total time of chromatography is $8 \mathrm{~min}$, which makes it possible to make $30-40$ manual analyses per day (without autosampler). The developed method was successfully applied for carrying out of pharmacokinetic studies and researches on studying bioequivalence of drugs containing verapamil $[134,135]$.

Scientists Stagni G. and Gillespie W. R. described the method for the determination of verapamil and its norverapamil metabolite in blood plasma. Norverapamil is rapidly acetylated to $N$ acetylnorverapamil using $2 \%$ butanol in hexane. Verapamil and $N$ acetylnorverapamil are separated by $\alpha$-glycoprotein chiral column by mobile phase-a mixture of phosphate buffered solution $(0.01 \mathrm{M}$, $\mathrm{pH}$ 6.65) and acetonitrile. The wavelengths of the fluorescence detector were set at $227 \mathrm{~nm}$ for excitation and $308 \mathrm{~nm}$ for radiation. The method was linear in the range of concentrations of 3-200 $\mathrm{ng} / \mathrm{ml}$ of verapamil and $2-100 \mathrm{ng} / \mathrm{ml}$ of norverapamil. LOD of verapamil was $3 \mathrm{ng} / \mathrm{ml}$ and norverapamil- $2 \mathrm{ng} / \mathrm{ml}$. The developed method was used to study pharmacodynamics [136].

Jhee $\mathrm{OH}$ et al. developed the bioanalytical method for determining verapamil in plasma of rats using mobile phase A $(50 \mathrm{mmol}$ ammonium phosphate, $\mathrm{pH} 4.5$ ) and mobile phase $\mathrm{B}(50 \mathrm{mmol}$ ammonium phosphate: acetonitrile, 70:30 v/v). Analysis of verapamil and internal standard of propranolol were performed by direct introduction of rat plasma into the system and eluted, respectively, $22 \mathrm{~min}$ (verapamil) and $12 \mathrm{~min}$ (propranolol) at mobile phase A of $0.5 \mathrm{ml} / \mathrm{min}$ and mobile phase B of $0.15 \mathrm{ml} / \mathrm{min}$. The method was validated. The correlation coefficient was 0.9997 . The method was linear in the range of 0.01 to $2.50 \mu \mathrm{g} / \mathrm{ml}$. LOD-0.01 $\mu \mathrm{g} / \mathrm{ml}, \mathrm{LOQ}-0.025 \mu \mathrm{g} / \mathrm{ml}$. The developed method was successfully used for the study of pharmacokinetics $[137,138]$.

The method of reverse HPLC/UV determination of verapamil in blood plasma was developed by Muscara M. N. and de-Nucci G. Flecainide was used as internal standard. The method was completely validated and used for pharmacokinetic studies [139].

Scientists Lau-Cam C. A. and Piemontese D. proposed the HPLC/UV method for determining verapamil in plasma of rats using dextromethorphan as an internal standard and mobile phase-a mixture of methanol, acetonitrile, triethylamine acetate buffer solution $(10: 30: 60 \mathrm{~V} / \mathrm{V} / \mathrm{V} /)$ with detection wavelength of $235 \mathrm{~nm}$, flow rate of $1.5 \mathrm{ml} / \mathrm{min}$. The method was linear in the concentration range of $0.5-10 \mu \mathrm{g} / \mathrm{ml}$ (correlation coefficient-0.9999). LOD-0.1 $\mu \mathrm{g} / \mathrm{ml}$. The method was used to monitor the concentration of verapamil in the plasma of rats receiving this drug through various routes of administration [140].

Scientists Hedeland M., Fredriksson E., Lennernäs H., Bondesson U. described the bioanalytical method for the determination of verapamil enantiomers and their $N$-dimethylated metabolite in blood plasma using HPLC/MS. The mobile phase-a mixture of $85 \%$ aqueous solution of ammonium acetate $\mathrm{pH} 7.4$ and a $15 \%$ solution of 
acetonitrile, flow rate- $0.6 \mathrm{ml} / \mathrm{min}$. The developed method was successfully applied for the study of in vivo intestinal permeability [141-144].

\section{CONCLUSION}

From the above-mentioned, we can conclude that analysts are constantly working on developing new methods of analysis and their optimization in order to save time and consumables, which also ensures the efficiency of the developed method. The main disadvantage of the described methods of API analysis can be considered long term from the beginning of chromatography to API release and specific solvents used as the mobile phase in HPLC. In our opinion, it is necessary to develop methods and to select such chromatographic conditions that will provide high speed and high efficiency at lower pressure of the system. This reduces the amount of used mobile phase, which reduces cost analysis accordingly, while at the same time providing the necessary specificity, accuracy and reproducibility of the results of the analysis during quality control. Also, the reduction of analysis time is achieved by simplifying the conditions for sample preparation.

\section{AUTHORS CONTRIBUTIONS}

All the author have contributed equally

\section{CONFLICT OF INTERESTS}

\section{Declared none}

\section{REFERENCES}

1. https://www.mayoclinic.org/diseases-conditions/high-bloodpressure/in-depth/calcium-channel-blockers/art-20047605. [Last accessed on 10 Jan 2019]

2. https://en.wikipedia.org/wiki/Calcium_channel_blocker. [Last accessed on 10 Jan 2019]

3. https://pubchem.ncbi.nlm.nih.gov. [Last accessed on 10 Jan 2019].

4. Altiokka G, Altiokka M. Flow injection analysis of amlodipine using UV-detection. Pharmazie 2002;57:500-3.

5. Gohil K, Trivedi P, Molvi KI. Spectrophotometric analysis of amlodipine besylate in bulk and in tablet dosage forms. Indian J Pharma Sci 2005;67:376-8.

6. Chaudhari BG, Patel AB. Simultaneous spectrophotometric estimation of atorvastatin calcium and amlodipine besylate in tablet dosage forms. Int J Chem Tech Res 2010;2:633-9.

7. Dake AS, Kasture VS, Ryed M. A kinetic spectrophotometric method for determination of amlodipine and nifedipine in pharmaceutical preparations. Indian Drugs 2002;39:14-7.

8. Jain HK, Agrawal RK. Spectrophotometric method for simultaneous estimation of amlodipine besylate and lisinopril in tablet. Indian Drugs 2000;37:196-9.

9. Sahu R, Patel Vandana B. Simultaneous spectrophotometric determination of amlodipine besylate and atorvastatin calcium in binary mixture. Indian J Pharma Sci 2007;69:110-1.

10. Khan MR, Jain Deepti. Simultaneous spectrophotometric determination of atorvastatin calcium and amlodipine besylate in tablets. Indian J Pharma Sci 2006;68:546-8.

11. Meyya SN, Nathan GV, Suresh B. Simultaneous spectrophotometric estimation of benazepril and amlodipine besylate in their dosage form. Indian Pharmacist 2003;2:100-1.

12. Prasad CVN, Saha RN, Parimoo P. Simultaneous determination of amlodipine-enalapril maleate and amlodipine-lisinopril in combined tablet preparations by derivative spectrophotometry. Pharm Pharmacol Comm 1999;5:383-8.

13. Ragno G, Garofalo A, Vetuschi C. Photodegradation monitering of amlodipine by derivative spectrophotometry. J Pharm Biomed Anal 2002;27:19-24.

14. Ayad MM, Abdellatef HE, Hosny MM, Sharaf YA. Spectrophotometric and spectrofluorimetric determination of amlodipine besilate and doxazosin mesilate in bulk and in dosage forms. Int J Pharm Biomed Res 2012;3:111-6.

15. Basavaiah K, Chandrashekar U, Nagegowda P. Spectrophotometric and high performance liquid chromatographic determination of amlodipine besylate in pharmaceuticals. Sci Asia 2005;31:13-21.
16. Wankhede SB, Raka KC, Wadkar SB, Chitlange SS. Spectrophotometric and HPLC methods for simultaneous estimation of amlodipine besilate, losartan potassium and hydrochlorothiazide in tablets. Indian J Pharm Sci 2010;72:136-40.

17. Bhushan R, Gupta D, Singh SK. Liquid chromatographic separation and UV determination of certain antihypertensive agents. Biomed Chromatogr 2006;20:217-24.

18. Alizadeh N, Hemati F.Spectrophotometric method for the determination of amlodipine besylate in pure and dosage forms using 7,7,8,8-tetracyanoquinodimethane and tetracyanoethylene. Bull Faculty Pharm Cairo University 2014;52:109-14.

19. Hemmateenejad B, Miri R, Kamali R. A kinetic spectrophotometric method for determination of amlodipine and nifedipine in pharmaceutical preparations. J Iran Chem Soc 2009;1:113-20.

20. Mahmoud AM, Abdel Wadood HM, Mohamed NA. Kinetic spectrophotometric method for determination of amlodipine besylate in its pharmaceutical tablets. J Pharm Anal 2012;2:334-41.

21. Mohammadi A. A stability-indicating high performance liquid chromatographic (HPLC) assay for the simultaneous determination of atorvastatin and amlodipine in commercial tablets. J Chromatogr B 2007;846:215-21.

22. Aravindraju S, Muralidharan S, Meyyanathan SN, Suresh B. A validated RP-HPLC method for simultaneous estimation of losartan potassium and amlodipine in pharmaceutical formulation. Anal Chem (Rajkot, India) 2006;3:66-70.

23. Sivakumar T, Manavalan R, Muralidharan C, Valliappan K. An improved HPLC method with the aid of a chemometric protocol: simultaneous analysis of amlodipine and atorvastatin in pharmaceutical formulations. J Sep Sci 2007;30:3143-53.

24. Kumar DB. Analytical method development and validation of amlodipine and benazepril hydrochloride in combined dosage form by RP-HPLC. Int J Chem Pharm Sci 2011;2:26-30.

25. Argekar AP, Powar SG. Simultaneous determination of atenolol and amlodipine in tablets by high-performance thin-layer chromatography. J Pharm Biomed Anal 2000;21:1137-42.

26. Aryal S, Skalko Basnet N. Stability of amlodipine besylate and atenolol in multi-component tablets of mono-layer and bi-layer types. Acta Pharm 2008;58:299-308.

27. Avadhanulu AB, Srinivas JS, Anjaneyulu Y. Reverse phase HPLC determination of amlodipine besylate in drug and its pharmaceutical dosage forms. Indian Drugs 1996;33:36-40.

28. Bharat G Chaudhari. Development and validation of RP-HPLC method for simultaneous stimation of enalapril maleate and amlodipine besylate in combined dosage form. J Appl Pharm Sci 2012;2:54-7.

29. Bhushan R, Tanwar S. Reversed-phase high-performance liquid chromatographic enantioresolution of six $\beta$-blockers using dinitrophenyl-l-Pro-N-hydroxysuccinimide ester, Nsuccinimidyl-(S)-2-(6-methoxynaphth-2-yl) propionate and twelve variants of sanger's reagent as chiral derivatizing reagents. Biomed Chromatography 2009;23:1291-9.

30. Chitlange S, Imran M, Sakarkar D. RP-HPLC method for simultaneous estimation of amlodipine and metoprolol in tablet formulation. Asian J Pharm 2008;2:232.

31. Chitlange SS, Bagri K, Sakarkar DM. Stability indicating RP-HPLC method for simultaneous estimation of valsartan and amlodipine in capsule formulation. Asian J Res Chem 2008;7:15-8.

32. Pandya KK, Satia M, Gandhi TP, Modi IA. Detection and determination of total amlodipine by high-performance thinlayer chromatography: a useful technique for pharmacokinetic studies. J Chromatogr B 1995;667:315-20.

33. Malesuik MD. Determination of amlodipine in pharmaceutical dosage forms by liquid chromatography and ultraviolet spectrophotometry. J Pharm Biomed Anal 2005;89:359-64.

34. Altiokka G, Dogrukol-Ak D, Tuncel M, Aboul Enein HY. Determination of amlodipine in pharmaceutical formulations by differential-pulse voltammetry with a glassy carbon electrode. Archiv Der Pharmazie (Weinheim) 2002;335:104-8.

35. Dai SY, Qiu ST, Wu W, Fu CM. Development and validation an RP-HPLC method for simultaneous determination of ramipril and amlodipine in tablets. J Pharma Anal 2013;3:440-6. 
36. Prathyusha W. Development and validation of a stability indicating RP-HPLC method for simultaneous estimation of aliskerin hemifumarate, amlodipine besylate and hydrochlorothiazide in bulk and pharmaceutical dosage forms. J Pharm Bio Sci 2014;9:114-23.

37. Momin MAM, Islam MM, Rahman KH, Sh Md Anisuzzaman. Development and validation of assay method of amlodipine tablet by HPLC. Int J Pharm Phytopharmacol Res 2012;2:109-15.

38. Pathak SU, Saple SR, Vaidya VV, Kekare MB. Development and validation of RP-HPLC methods for simultaneous estimation of amlodipine, hydrochlorothiazide and olmesartan medoxomil in tablets formulation. Anal Chem Indian J 2011;10:624-7.

39. Moon HW. Evaluation of stability and simultaneous determination of fimasartan and amlodipine by a HPLC method in combination tablets. Asian J Pharma Sci 2014;9:123-8.

40. Gawri N, Vaidhyalingam V, Santha A. HPTLC method for the simultaneous estimation of amlodipine besylate and benazepril $\mathrm{HCl}$ tablets. Indian Drugs 2003;40:645-8.

41. Gowri N, Vaidhyalingam V, Santha A. Simultaneous estimation of amlodipine and benazepril from tablet by RP-HPLC. Indian Drugs 2002;39:532-5.

42. Halkar UP, Bhandari NP, Rane SH. High performance liquid chromatographic simultaneous determination of amlodipine and enalapril maleate from pharmaceutical preparations. Indian Drugs 1998;35:168-9.

43. Kul D. High-performance liquid chromatographic and first derivative of the ratio spectrophotometric determination of amlodipine and valsartan in their binary mixtures. J AOAC Int 2010;93:882-90.

44. Kulkarni AP, Gat GV, Pimple SV, Joshi MA. HPLC method for determination of losartan potassium and amlodipine besylate in tablets. Indian Drugs 2003;40:298-9.

45. Ilango K, Kumar PB, Lakshmi KS. Simple and rapid HPTLC estimation of amlodipine and atenolol from pharmaceutical dosages. Indian Drugs 2000;37:497-9.

46. Kamble N, Venkatachalam A. Determination and validation of HPLC method for simultaneous determination of lisinopril and amlodipine from tablet. Indian Drugs 2004;41:179-81.

47. Kavathia A, Misra M. Development and validation of RP-HPLC and UV-spectrophotometric methods for rapid simultaneous estimation of amlodipine andbenazepril in pure and fixed dose combination. Arabian J Chem 2013;10 Suppl 2:S3021-S3028.

48. Kazemipour M. Use of adsorptive square-wave anodic stripping voltammetry at carbon paste electrode for the determination of amlodipine besylate in the pharmaceutical preparations. Журн Аналит Химии 2009;64:74-9.

49. Li C, Yan X, Shan W. HPLC determination of amlodipine besylate tablets. Yaowu Fenxi Zazhi 2006;26:1878-9.

50. Shalini P, Krishan P. Development and validation of a simultaneous HPLC method for assay and dissolution of bisoprolol fumarate and amlodipine besylate in pharmaceutical dosage. Res J Pharm Dosage Forms Technol 2012;4:62-6.

51. Kayal SD. Method development and validation for the simultaneous determination of amlodipine besylate and telmisartan in tablet dosage form by RP-HPLC. Int J Pharm Res Dev 2011;3:144-53.

52. Meyyanathan SN, Suresh B. HPTLC method for the simultaneous determination of amlodipine and benazepril in their formulations. J Chromatogr Sci 2005;43:73-5.

53. Naidu KK, Kale UN, Shingare MS. Stability indicating RPHPLC method for simultaneous determination of amlodipine and benazepril hydrochloride from their combination drug product. J Pharm Biomed Anal 2005;39:147-55.

54. Patki RV, Tamhankar CP, Tipnis HP. Simple and rapid high performance liquid chromatographic estimation of amlodipine from pharmaceutical dosage. Indian Drugs 1994;31:560-1.

55. Rajkondawar VV. Simultaneous determination of atorvastatin and amlodipine by reverse phase high performance liquid chromatography. Asian J Chem 2006;18:3227-9.

56. Raju VB, Rao AL. Simultaneous estimation of perindopril and amlodipine in combined dosage form by RP-HPLC method. Int J Chem Sci 2011;9:1290-7.
57. Shah DA. RP-HPLC determination of atorvastatin calcium and amlodipine besylate combination in tablets. Indian J Pharm Sci 2006;68:796-9.

58. Rajeswari KR. RP-HPLC method for the simultaneous determination of atorvastatin and amlodipine in tablet dosage form. Indian J Pharm Sci 2006;68:275-7.

59. Rao MMP, Rahaman SA, Prasad YR, Reddy PG. RP-HPLC method of simultaneous estimation of amlodipine besylate and metoprolol in combined dosage form. Int J Pharma Res Dev 2010;2:69-76.

60. Luksa J. Semi-preparative chromatographic purification of the enantiomers S-(-)-amlodipine and R-(+)-amlodipine. J Chromatogr B 1997;693:367-75.

61. Shang F, Shang K. Determination of amlodipine in tablets by HPLC. Zhongguo Yiyao Gongye Zazhi 1996;27:411-3.

62. Shah DA. Stability indicating RP-HPLC estimation of atorvastatin calcium and amlodipine besylate in pharmaceutical formulations. Indian J Pharm Sci 2008;70:754-60.

63. Xiao H, Wang Y. Study on preparation and quality standard of amlodipine besylate tablets. Zhongguo Yaoye 2007;16:30-2.

64. Yeole MP, Asnani AJ. Simultaneous determination of telmisartan and amlodipine in tablets by reverse phase high performance liquid chromatography. Res J Pharm Technol 2011;4:75-7.

65. Bhatt J. A rapid and sensitive liquid chromatography-tandem mass spectrometry (LC-MS/MS) method for the estimation of amlodipine in human plasma. J Biomed Chromatogr Sci Appl 2007;21:169-75.

66. Alsarra IA. High-performance liquid chromatographic method for quantitative determination of amlodipine in human plasma and pharmaceutical dosage form and its application to pharmacokinetic studies. J Chromatogr Sci 2009;47:863-7.

67. Feng Y. Analysis of amlodipine in human plasma by liquid chromatography-mass spectrometry. J Chromatogr Sci Appl 2002;40:49-53.

68. Zarghi A, Foroutan SM, Shafaati A, Khoddam A. Validated HPLC method for determination of amlodipine in human plasma and its application to pharmacokinetic studies. Farmaco 2005;60:789-92.

69. Bahrami G, Mirzaeei S. Simple and rapid HPLC method for determination of amlodipine in human serum with fluorescence detection and its use in pharmacokinetic studies. J Pharm Biomed Anal 2004;36:163-8.

70. Streel B. Enantiomeric determination of amlodipine in human plasma by liquid chromatography coupledto tandem mass spectrometry. J Biochem Biophys Methods 2002;54:357-68.

71. Ma Y. Determination and pharmacokinetic study of amlodipine in human plasma by ultra performance liquid chromatographyelectrospray ionization mass spectrometry. J Pharm Biomed Anal 2007;43:1540-5.

72. Freddy $\mathrm{H}$, Chaudhari V.Simultaneous determination of atorvastatin calcium and amlodipine besylate from pharmaceutical formulation by reversed phase high performance liquid chromatography. Asian J Chem 2005;7:2502-8.

73. Yu Q. HPLC-MS-MS for the simultaneous determination of atorvastatin and amlodipine in plasma of hypertensive patients. Chromatographia 2011;73:257-62.

74. Wei X, Yang G, Qi L, Chen Y. Determination of nicardipine and amlodipine in human plasma using on-line solid-phase extraction with a monolithic weak cation-exchange column. Talanta 2009;77:1197-202.

75. Ramani AV, Sengupta P, Mullangi R. Development and validation of a highly sensitive and robust LC-ESI-MS/MS method for simultaneous quantitation of simvastatin acid, amlodipine and valsartan in human plasma: application to a clinical pharmacokinetic study. Biomed Chromatogr 2009;23:615-22.

76. Yuliya Kondratova, Liliya Logoyda, Yuliia Voloshko, Ahmed Abdel-Megied, Dmytro Korobko, Yuriy Soroka. Development and validation of HPLC-DAD method for the determination of bisoprolol in tablet dosage forms. Int J Appl Pharm 2017;9:54-9.

77. Kondratova Y, Adebayo T, Logoyda L, Korobko D, Berdey I, Kuchmerovska T. Development of the methodology of the chromatographic determination of amlodipine in medicines. Int J Res Ayurveda Pharm 2016;7:32-5. 
78. Liliya Logoyda, Yuliya Kondratova, Dmytro Korobko, Yuriy Soroka. Development of UHPLC method for the determination of captopril in pharmaceutical dosage forms. Asian J Pharm Clin Res 2017;10:308-10.

79. Liliya Logoyda, Ahmed M Abdel-Megied, Yuliya Kondratova, Olena Trofimenko, Dmytro Korobko, Iryna Dakhym. Development and validation of HPLC method for the simultaneous determination of enalapril maleate in present of their impurities: application to tablet analysis. Int J Appl Pharm 2018;10:98-102.

80. Liliya L, Dmytro K, Olena S, Ihor B, Tamara K. Development of methodology for identification of captopril in medicines. Asian J Pharm 2016;10:168-71.

81. Logoyda L, Korobko D, Saprun S, Zarivna N. Development of methods for the chromatographic identification of active pharmaceutical ingredient from group of angiotensinconverting enzyme inhibitors in pharmaceuticals. Int J Green Pharm 2017;11 Suppl:737-41.

82. Liliya Logoyda, Dmytro Korobko, Iryna Ivanusa, Kovalenko Serhii. Development of the methodology of the chromatographic determination of nifedipine in medicines. Asian J Pharm Clin Res 2017;10:149-52.

83. Logoyda Liliya, Korobko Dmutro, Saprun Stanislav. Development of methods for identification of calcium channel blockers in medicines. Int J Res Ayurveda Pharm 2016;7:88-91.

84. Olgya Polyauk, Liliya Logoyda. The investigation of conditions of API from group of calcium channel blockers extraction by organic solvents by using high-performance liquid chromatography as method assay. Asian J Pharm Clin Res 2017;10:354-6.

85. Kondratova Y, Adebayo T, Logoyda L, Korobko D, Berdey I, Kuchmerovska T. Development of the methodology of the chromatographic determination of amlodipine in medicines. Int J Res Ayurveda Pharm 2016;7:32-5.

86. Logoyda L, Abdel Megied AM, Kondratova Y, Trofimenko O, Korobko D, Dakhym I. Development and validation of HPLC method for the simultaneous determination of enalapril maleate in present of their impurities: application to tablet analysis. Int J Appl Pharm 2018;10:98-102.

87. Liliya Logoyda, Dmytro Korobko, Oleksandra Oleshchuk, Taras Proniv, Mariya Dmutriv. A HPLC MS/MS method development and validation for the simultaneous determination of bisoprolol and enalapril in the present of enalaprilat in human plasma. Int J Appl Pharm 2018;10:31-40.

88. Logoyda L, Mykhalkiv M, Polyauk O, Zarivna N, Soroka Y, Demydiak O. Ultra-high-performance liquid chromatography as assay method for the investigation of conditions of captopril extraction by organic solvents. Asian J Pharma 2018;12 Suppl:111-4.

89. Mykhalkiv M, Logoyda L, Polyauk O, Zarivna N, Soroka Y, Ryabokon S, et al. HPLC as assay method for the investigation of conditions of bisoprolol extraction by organic solvents. Int J Green Pharm 2018;12 Suppl:276-9.

90. Liliya Logoyda. Bioanalytical method development and validation from the simultaneous determination of verapamil and enalapril in the present of enalaprilat by HPLC MS/MS. Int J Appl Pharm 2018;10:19-27.

91. Liliya Logoyda. Quantitative determination of amlodipine from Caco-2 cell monolayers by high-performance liquid chromatography-mass spectrometry/mass spectrometry. Asian J Pharm Clin Res 2018;11:204-7.

92. Yuryeva O, Kondratova Y, Logoyda L. Development of highperformance liquid chromatography method for simultaneous analysis of amlodipine and valsartan in combined dosage form and in vitro disslotution studies. Asian J Pharm Clin Res 2018;11:200-4.

93. Mykhalkiv M, Logoyda L, Ivanusa I, Soroka Y, Yakubishyna I. High-performance liquid chromatography as assay method for the investigation of conditions of enalapril maleate extraction by organic solvents. Int J Green Pharm 2018;12:62-65.

94. Logoyda L, Kondratova Y, Korobko D, Susla O, Soroka Y, Tsytsiura R, et al. Youden's test of the chromatographic determination of captopril in pharmaceuticals. Int J Green Pharm 2017;11:188-91.

95. Liliya Logoyda. A high-performance liquid chromatographymass spectrometry method development for the quantitative determination of enalapril maleate from Caco-2 cell monolayers. Asian J Pharm Clin Res 2018;11:89-92.

96. Logoyda L, Korobko D. A high-performance liquid chromatography-mass spectrometry/mass spectrometry method development for the quantitative determination of bisoprolol from Caco-2 cell monolayers. Asian J Pharm Clin Res 2018;11:386-9.

97. Liliya Logoyda. A HPLC-MS/MS method development and validation for the simultaneous determination of nifedipine and enalapril in human plasma. Int J Appl Pharm 2018;10:35-42.

98. Dinakaran SK. Spectrophotometric method development and validation for atorvastatin calcium and nifedipine $\mathrm{HCl}$ in bulk and tablet dosage form using absorption ratio method assay of atorvastatin and nifedipine. J Pharm Res 2013;7:666-9.

99. Revathi R. New spectroscopic determination of nifedipine using hydrotropic solubilization. Int J Pharm Pharm Sci 2010;2:74-6.

100. Hamidi N, Taib MN, Wui WT. Analysis of nifedipine content in transdermal drug delivery system using non-destructive visible spectrophotometry technique. Malaysian J Anal Sci 2008;12:348-51.

101. Tulasamma P, Venkateswarlu P. Spectrophotometric determination of nifedipine in pharmaceutical formulations, serum and urine samples via oxidative coupling reaction. Arabian J Chem 2016;9(Suppl 2):S1603-S1609.

102. Modi Dixita V, Patel Paresh U. Development and validation of simultaneous equation method for simultaneous estimation of telmisartan and nifedipine in synthetic mixture. Int Res J Pharm 2016;7:6-9.

103. Al-Ghannam SM, AlOlyan AM. Spectrofluorometric determination of nicardipine, nifedipine and isradipine in pharmaceutical preparations and biological fluids. Centr Eur J Chem 2008;6:222-8.

104. Bing L, Hu DF, Liu F. HPLC determination of atenolol and nifedipine in compound atenolol tablets. Yaowu Fenxi Zazhi 2004;24:485-6.

105. Galan Rodriguez C, González Alvarez J, Valls Remolí M. Method development and validation study for quantitative determination of nifedipine and related substances by ultra-high-performance liquid chromatography. Biomed Chromatogr 2015;29:233-9.

106. DM Milenovic, ML Lazic, VB Veljkovic, ZB Todorovic. Validation of an HPLC method for analysis of nifedipine residues on stainless-steel surfaces in the manufacture of pharmaceuticals. Acta Chromatographica 2008;20:183-94.

107. Rosseel MT, Bogaert MG. Determination of nifedipine in human plasma by capillary gas chromatography with nitrogen detection. J Chromatogr 1983;279:675-80.

108. Soons PA, Schellens JH, Roosemalen MC, Breimer DD. Analysis of nifedipine and its pyridine metabolite dehydronifedipine in blood and plasma: review and improved high-performance liquid chromatographic methodology. J Pharm Biomed Anal 1991;9:475-84

109. Guo Y. Determination of nifedipine in human plasma and its use in bioequivalence study. Int J Pharm 2007;341:91-6.

110. Wang D. Determination of nifedipine in human plasma by ultra performance liquid chromatography-tandem mass spectrometry and its application in a pharmacokinetic study. J Chromatography B 2011;879:1827-32.

111. Guellec C Le, Bun H, Giocanti M, Durand A. Determination of nifedipine in plasma by a rapid capillary gas chromatographic method. Biomed Chromatogr 1992;6:20-3.

112. Zendelovska D.Development of an HPLC method for the determination of nifedipine in human plasma by solid-phase extraction. J Chromatogr B: Anal Technol Biomed Life Sci 2006;839:85-8.

113. Patrick KS, Jarvi EJ, Straughn AB, Meyer MC. Gas chromatographic mass spectrometric analysis of plasma nifedipine. J Chromatogr 1989;495:123-30.

114. Gurley BJ, Buice RG, Sidhu P. Reversed-phase high performance liquid chromatographic determination of nifedipine in human plasma. Ther Drug Monit 1985;7:321-3.

115. Jankowski A, Lamparczyk H. Evaluation of chromatographic methods for the determination of nifedipine in human serum. J Chromatogr A 1994;668:469-73.

116. Abou-Auda HS. Liquid chromatographic assay of nifedipine in human plasma and its application to pharmacokinetic studies. J Pharm Biomed Anal 2000;22:241-9. 
117. Mosab A, Zahaa A, Momir M. Determination of nifedipine in rat plasma using HPLC-UV detector: a simple method for pharmacokinetics and oral bioavailability studies. Int J Pharm Sci 2016;8:98-102.

118. Yritia M, Parra P, Iglesias E, Barbanoj JM. Quantitation of nifedipine in human plasma by on-line solid-phase extraction and high-performance liquid chromatography. J Chromatogr A 2000;870:115-9.

119. Wang XD. Rapid and simultaneous determination of nifedipine and dehydronifedipine in human plasma by liquid chromatography-tandem mass spectrometry: application to a clinical herb-drug interaction study. J Chromatogr B: Anal Technol Biomed Life Sci 2007;852:534-44.

120. Schmid BJ, Perry HE, Idle JR. Determination of nifedipine and its three principal metabolites in plasma and urine by automated electron-capture capillary gas chromatography. J Chromatogr 1988;425:107-19.

121. Streel B, Zimmer C, Sibenaler R, Ceccato A. Simultaneous determination of nifedipine and dehydronifedipine in human plasma by liquid chromatography-tandem mass spectrometry. J Chromatogr B: Biomed Sci Appl 1998;720:119-28.

122. Salh DM. Spectrophotometric determination of isoptin (Verapamil Hydrochloride) in pharmaceutical preparations using bromothymol blue reagent. Int J Chem Environ Eng 2012;3:15-20.

123. Rahman N, Hoda MN. Spectrophotometric determination of verapamil hydrochloride in drug formations with chloramine- $\mathrm{T}$ as oxidant. Anal Bioanal Chem 2002;374:484-9.

124. Rahman N, Hejaz Azmi SN. Spectrophotometric method for the determination of verapamil hydrochloride in pharmaceutical formulations using $\mathrm{N}$-bromosuccinimide as oxidant. Farmaco 2004;59:529-36.

125. Rahman N, Khan NA, Hejaz Azmi SN. Optimized and validated spectrophotometric methods for the determination of verapamil hydrochloride in drug formulations. Sci Asia 2005;31:341-8.

126. Hasanzadeh M, Pournaghi Azar MH, Shadjou N, Jouyban A. A verapamil electrochemical sensor based on magnetic mobile crystalline material-41 grafted by sulfonic acid. Electrochimica Acta 2013;89:660-8.

127. Chen A, Tsao MJ, Chuang JF, Lin Ch H. Electrochemical determination of verapamil with a microchip embedded with gold nanoelectrode ensemble electrodes. Electrochimica Acta 2013;89:700-7.

128. Li-Jun LI. Electrochemiluminescence of sodium dodecyl sulfateru(bpy)3 2+-verapamil hydrochloride system and its application. Chin J Anal Chem 2011;39:1033-7.

129. Semaan FS, Cavalheiro ETG, Brett Ch MA. Electrochemical behavior of verapamil at graphite-polyurethane composite electrodes: determination of release profiles in pharmaceutical samples. Anal Lett 2009;42:1119-35.

130. Srinivasan V, Sivaramakrishnan H, Karthikeyan B. Detection, isolation and characterization of principal synthetic route indicative impurities in verapamil hydrochloride. Sci Pharm 2011;79:555-68.
131. Ivanova V, Zendelovska D, Stefova M, Stafilov T. HPLC method for determination of verapamil in human plasma after solid-phase extraction. J Biochem Biophys Methods 2008;70:1297-303.

132. Unadkat JD. Rapid solid-phase extraction method to quantify ${ }^{11} \mathrm{C}$-verapamil, and its ${ }^{11} \mathrm{C}$-metabolites, in human and macaque plasma. Nucl Med Biol 2008;35:911-7.

133. Mallik R, Yoo MJ, Chen S, Hage DS. Studies of verapamil binding to human serum albumin by high-performance affinity chromatography. J Chromatogr B: Biomed Sci Appl 2008;876:69-75.

134. Sawicki W. A validated method for the determination of verapamil and norverapamil in human plasma. J Pharm Biomed Anal 2001;25:689-95.

135. Hubert PH. Determination of verapamil and norverapamil in human plasma by liquid chromatography: comparison between a liquid-liquid extraction procedure and an automated liquidsolid extraction method for sample preparation. J Pharm Biomed Anal 1992;10:937-42.

136. Stagni G, Gillespie WR. Simultaneous analysis of verapamil and norverapamil enantiomers in human plasma by highperformance liquid chromatography. J Chromatogr B 1995;667:349-54.

137. Jhee $\mathrm{OH}$. Direct determination of verapamil in rat plasma by coupled column microbore HPLC method. J Pharm Biomed Anal 2005;37:405-10.

138. Negrusz A, Wacek BC, Toerne T, Bryant J. Quantitation of verapamil and norverapamil in postmortem and clinical samples using liquid-liquid extraction, solid phase extraction, and HPLC. Chromatographia 1997;46:191-6.

139. Muscara MN, de-Nucci G. Measurement of plasma verapamil levels by high-performance liquid chromatography. Braz J Med Biol Res 1993;26:753-63.

140. Lau Cam CA, Piemontese D. Simplified reversed-phase HPLC method with spectrophotometic detection for the assay of verapamil in rat plasma. J Pharm Biomed Anal 1998;16:1029-35.

141. M Hedeland, E Fredriksson, H Lennernäs, U Bondesson. Simultaneous quantification of the enantiomers of verapamil and its $\mathrm{N}$-demethylated metabolite in human plasma using liquid chromatography-tandem mass spectrometry. J Chromatogr B: Anal Technol Biomed Life Sci 2004;804:303-11.

142. Von Richter O, Eichelbaum M, Schonberger F, Hofmann U. Rapid and highly sensitive method for the determination of verapamil, [2H7] verapamil and metabolites in biological fluids by liquid chromatography-mass spectrometry. J Chromatogr B: Biomed Sci Appl 2000;738:137-47.

143. Krynytska I, Marushchak M, Zaets T, Savchenko I, Habor $\mathrm{H}$. Investigation of bone mineralization in patients with coronary heart disease complicated by chronic heart failure, stage II-A. Georgian Med News 2017;267:43-8.

144. Marushchak M, Krynytska I, Mikolenko A, Andreychyn Y, Bodnar Y, Chornomydz I. Chronic heart failure causes osteopathy or is osteopathy a factor in development of chronic heart failure. Asian J Pharm Clin Res 2018;11:111-5. 